\title{
Pengaruh Model Pembelajaran Survey, Question, Read, Recite, Review, Reflect Berbantuan Media Teks Cerita Rakyat terhadap Kompetensi Membaca Pemahaman Mata Pelajaran Bahasa Indonesia
}

\author{
Ni Putu Venny Fatma Dewi ${ }^{1 *}$, Ni Nyoman Ganing 2 , I Gusti Agung Oka Negara ${ }^{3}$
}

123Jurusan Pendidikan Guru Sekolah Dasar, FIP, Universitas Pendidikan Ganesha, Indonesia

\author{
A R T I CLEINFO \\ Article history: \\ Received 18 May 2019 \\ Received in revised form \\ 30 June 2019 \\ Accepted 15 July 2019 \\ Available online 25 August \\ 2019 \\ Kata Kunci: \\ $S Q 4 R$, teks cerita rakyat, \\ kompetensi membaca \\ pemahaman, bahasa \\ Indonesia \\ Keywords: \\ $S Q 4 R$, folklore text, reading \\ comprehension competency \\ of Bahasa Indonesia course
}

\begin{abstract}
A B S T R A K
Tujuan penelitian ini untuk mengetahui pengaruh model pembelajaran SQ4R berbantuan media teks cerita rakyat terhadap kompetensi membaca pemahaman mata pelajaran Bahasa Indonesia kelas V sekolah dasar Gugus Pattimura Denpasar Selatan 2017/2018. Penelitian ini berjenis eksperimen semu, dengan bentuk Non-ekuivalen control group design. Seluruh siswa kelas V SD gugus Pattimura sebanyak 341 siswa dijadikan populasi penelitian, Sampel ditentukan dengan teknik random sampling. Sampel dalam penelitian ini adalah kelas VA SDN 7 Sesetan sebagai kelompok eksperimen sebanyak 39 siswa, dan kelas V SDN 18 Sesetan sebagai kelompok kontrol sebanyak 37 siswa. Data hasil kompetensi membaca pemahaman mata pelajaran bahasa Indonesia dikumpulkan dengan instrumen berupa tes objektif pilihan ganda berjumlah 20 butir tes yang telah divalidasi. Data dianalisis dengan uji-t. Hasil penelitian menunjukkan terdapat perbedaan yang signifikan kompetensi membaca pemahaman mata pelajaran bahasa Indonesia kelompok siswa yang dibelajarkan melalui model pembelajaran SQ4R berbantuan media teks cerita rakyat dengan kelompok siswa yang dibelajarkan melalui pembelajaran konvensional pada siswa kelas V SD Gugus Pattimura Denpasar Selatan 2017/2018. Sehingga disimpulkan bahwa model pembelajaran SQ4R berbantuan media teks cerita rakyat berpengaruh terhadap kompetensi membaca pemahaman mata pelajaran bahasa Indonesia siswa kelas V SD Gugus Pattimura Denpasar Selatan 2017/2018.
\end{abstract}

A B S T R A C T

The purpose of this study was to determine the effect of the SQ4R learning model assisted by folklore text media on the reading competence of Indonesian Language subjects in fifth grade Pattimura elementary school Denpasar Selatan 2017/2018. This research is a quasi-experimental type, in form of Non-equivalent control group design. All 34 fifth grade elementary school students of the Pattimura were made into the study population. The sample was determined by random sampling technique. The sample in this study was the VA class SDN 7 Sesetan as an experimental group with 39 students, and class V SDN 18 Sesetan as a control group with 37 students. The results of reading comprehension data in Indonesian subjects were collected with an instrument in the form of multiple choice objective tests with 20 items that have been validated. Data were analyzed by t-test. The results showed that there were significant differences in the reading competence of Indonesian language subject reading groups of students who were taught through the SQ4R learning model assisted by folklore text media and groups of students who were taught through conventional learning in fifth grade students at Pattimura Elementary School in South Denpasar 2017/2018. So it can be concluded that the SQ4R learning model assisted by folklore text media influences the reading competence of Indonesian language subjects in fifth grade at Pattimura Elementary School South Denpasar 2017/2018.

\footnotetext{
1 Corresponding author.

E-mail addresses: ni.putu.venny.fatma@undiksha.ac.id (Ni Putu Venny Fatma Dewi)
} 


\section{Pendahuluan}

Perkembangan ilmu pengetahuan dan teknologi telah memberikan dampak terhadap berbagai bidang, salah satunya adalah dalam bidang pendidikan. Pendidikan merupakan tolak ukur kemajuan suatu bangsa. Bangsa yang maju adalah bangsa yang mengutamakan pendidikan, karena pendidikan mempunyai peranan dalam mengembangkan sumber daya manusia yang berkualitas. Pasal 3 UU Nomor 20 Tahun 2003 tentang sistem Pendidikan Nasional dinyatakan bahwa Pendidikan Nasional bertujuan untuk berkembangnya potensi peserta didik agar menjadi manusia yang beriman dan bertakwa kepada Tuhan Yang Maha Esa, berakhlak mulia, sehat, berilmu, cakap, kreatif, mandiri, dan menjadi warga Negara yang demokratis serta bertanggung jawab. Upaya yang dilakukan pemerintah untuk melakukan perubahan dalam dunia pendidikan guna mencapai tujuan pendidikan dilaksanakan dengan adanya kurikulum. Undang-Undang Nomor 20 Tahun 2003 tentang Sistem Pendidikan Nasional dinyatakan bahwa kurikulum adalah seperangkat rencana dan pengaturan mengenai tujuan, isi, dan bahan pelajaran serta cara yang digunakan sebagai pedoman penyelenggaraan kegiatan pembelajaran untuk mencapai tujuan pendidikan tertentu. Sejak tahun ajaran 2013/2014 Kuriklum yang diterapkan pada Sekolah Dasar / Madrasah Ibtidaiyah adalah kurikulum 2013 (Permendikbud Nomor 57 tahun 2014 lampiran 1). Diterapkannya kurikulum 2013 "bertujuan untuk mempersiapkan insan Indonesia untuk memiliki kemampuan hidup sebagai pribadi dan warga Negara yang produktif, kreatif, inovatif dan afektif serta mampu berkontribusi pada kehidupan bermasyarakat, berbangsa, bernegara dan peradaban dunia" (Daryanto dan Sudjendro,2014:17).

Menurut Kurniaman (2013) Kurikulum berfungsi sebagai pedoman dalam pelaksanaan kegiatan pendidikan di sekolah bagi pihak-pihak yang terkait, baik secara langsung maupun tidak langsung, seperti pihak guru, kepala sekolah, pengawas, orangtua, masyarakat dan pihak siswa itu sendiri, dalam mengimplementasikan kurikulum 2013 sangat berbeda dengan kurikulum sebelumnya, masih banyak kendala yang kita ketahui sangat mempengaruhi hasil belajar, baik dari segi media yang di gunakan, penilaian pada kurikulum 2013 lebih rumit dibandingkan dengan kurikulum sebelumnya kemudian metode yang digunakan untuk menyampaikan materi pembelajaran yang ingin diajarkan belum efektif atau bahkan tidak sesuai dengan materi yang ingin disampaikan. Implementasi kurikulum 2013 di semua jenjang pendidikan memiliki peranan penting dalam semua mata pelajaran, salah satunya pembelajaran Bahasa Indonesia. BSNP dalam Susanto (2013:245) menyebutkan pembelajaran Bahasa Indonesia diarahkan untuk meningkatkan kemampuan peserta didik untuk berkomunikasi dalam bahasa Indonesia dengan baik dan benar, baik secara lisan maupun tulis. Tujuan pembelajaran Bahasa Indonesia di Sekolah Dasar adalah agar siswa mampu menikmati dan memanfaatkan karya sastra untuk mengembangkan kepribadian, dapat memperluas wawasan pengetahuan dan kemampuan berbahasa (Susanto,2013:245).

Dalam pembelajaran bahasa Indonesia dimaksudkan untuk melatih kemampuan menyimak, berbicara, menulis, serta membaca. Rahim (2011:1) menyatakan bahwa "proses belajar yang efektif antara lain dilakukan melalui membaca". Membaca merupakan kegiatan atau proses menerapkan sejumlah keterampilan mengolah teks bacaan dalam rangka memperoleh informasi atau pesan yang disampaikan oleh penulis dalam tuturan bahasa tulis (Dalman, 2017:1). Tujuan membaca secara umum ada tiga, yaitu (1) membaca untuk studi, (2) membaca untuk usaha, dan (3) membaca untuk kesenangan (Dalman, 2017:3). Dalam hal ini membaca adalah memahami makna dalam sebuah tulisan. (Dalman, 2017:87) "Membaca pemahaman adalah membaca secara kognitif (membaca untuk memahami)".

Menurut Rasjid (2015) Upaya meningkatkan mutu pendidikan membutuhkan proses belajar mengajar yang optimal, sehingga diperoleh hasil belajar, sesuai dengan tujuan yang diharapkan. Kesadaran baik dari siswa sebagai subjek yang harus terlibat secara aktif dalam proses belajar maupun guru sebagai pendidik sangat dibutuhkan, karena belajar pada hakikatnya adalah kegiatan yang dilakukan secara sadar oleh seseorang untuk menghasilkan perubahan tingkah laku pada dirinya sendiri, baik dalam bentuk pengetahuan dan keterampilan baru maupun dalam bentuk sikap dan nilai yang positif. Pada dasarnya, membaca pemahaman merupakan keterampilan membaca yang berada pada kelas tinggi, salah satunya pada kelas V SD. Membaca yang semula merupakan hal yang mudah dan mengasikan berubah menjadi hal yang sulit. Namun membaca sering kali dianggap remeh oleh sebagian siswa dan sangat membosankan. Dalam membaca pemahaman siswa tidak lagi dituntut bagaimana siswa tersebut melafalkan huruf dengan benar menjadi bentuk kata, tetapi siswa dituntut untuk memahami isi teks bacaan pada bacaan yang telah dibaca. Pada kenyatan di lapangan, banyak siswa yang mengalami kesulitan dalam membaca pemahaman, hal ini terbukti dari hasil observasi yang dilaksanakan pada tanggal 11 Januari 2018 di Gugus Patimura pada siswa kelas V ditemukan masalah dalam Pembelajaran bahasa Indonesia, yaitu minat membaca, rendahnya daya serap, serta kurangnya pemahaman siswa mengenai isi bacaan dari teks bacaan yang telah dibaca karena siswa menganggap bacaan yang dibaca tidak menarik. Sehingga kompetensi membaca pemahaman mata pelajaran bahasa 
Indonesia belum optimal. Terbukti dari kompetensi membaca pemahaman pada pembelajaran bahasa Indonesia kelas V SD Gugus Pattimura Denpasar selatan Tahun Ajaran 2018 diperoleh dari nilai Ulangan Akhir Semester I yaitu, dari 341 siswa yang belum mencapai Kriteria Ketuntasan Minimal(KKM) yang ditetapkan yakni 70,00, yaitu 219 siswa atau sekitar 64,22\%, sedangkan 122 siswa atau sekitar 35,77\% yang sudah mencapai KKM. Oleh karena itu membaca pemahaman harus mendapat perhatian yang lebih terutama pada siswa Sekolah Dasar, agar kemampuan membaca siswa dapat berkembang pada masa berikutnya. Dalam hal ini peran guru sangatlah penting dalam proses pembelajaran utnuk meningkatkan minat siswa terhadap pembelajaran bahasa Indonesia khususnya dalam membaca pemahaman agar nilai kompetemsi membaca pemahaman mata pelajaran bahasa Indonesia dapat dioptimalkan.

Berkaitan dengan hal tersebut, diketahui faktor-faktor yang menyebabkan rendahnya hasil kompetesi membaca pemahaman mata pelajaran bahasa Indonesia siswa, seperti : Kompetensi membaca pemahaman mata pelajaran bahasa Indonesia pada beberapa siswa kelas V SD Gusus Pattimura Denpasar Selatan Tahun Ajaran2017/2018 masih di bawah Kriteria Ketuntasan Minimal (KKM)., proses pembelajaran di Sekolah Dasar kelas V Gugus Pattimura Denpasar Selatan Tahun Ajaran 2018 untuk mata pelajaran bahasa Indonesia khususnya kompetensi membaca pemahaman masih sangat kurang, dikarenakan pembelajaran masih dianggap kurang menarik, dan membosankan, sehingga kompetensi membaca pemahaman pada mata pelajaran bahasa Indonesia yang dimiliki siswa masih belum optimal, penggunaan model pembelajaran dan media pembelajaran sebagai pendukung proses pembelajaran kurang bervariasi dan interaksi siswa dengan sumber belajar masih kurang, sehingga pembelajaran dikatakan membosankan dan kurang menarik.

Berdasarkan permasalahan terhadap kurangnya pemahaman siswa dalam membaca, perlu adanya inovasi dalam pembelajaran. Upaya ini sangatlah penting sebab dapat mengoptimalkan nilai dari kompetensi membaca pemahaman mata pelajaran bahasa Indonesia. Untuk tercapainya tujuan pembelajaran membaca pemahaman, salah satu model pembelajaran yang dapat terapkan guru dalam proses pembelajaran adalah model Survey, Question, Read, Recite, , Review, Reflect (SQ4R). Menurut Dewi (2018) Metode pembelajaran (instruction method) merupakan akumulasi konsep-konsep mengajar (teaching) dan konsep belajar (learning). Keduanya merupakan perpaduan dalam sistem pembelajaran yang melibatkan siswa, tujuan, materi, fasilitas, prosedur, alat atau media yang digunakan. Arti penting dari metode pembelajaran sangat tergantung dari kemodernan dan konvensional penerapannya. Beberapa hasil penelitian dalam penggunaan metode pembelajaran yang berhasil di dalam mewujudkan tujuan pendidikan adalah pembelajaran yang modern dan konvensional. Menurut Shoimin (2014) maksud dari model $S Q 4 R$ adalah (1) mencermati teks bacaan dan mencatat kata kunci, (2) membuat pertanyaan mengenai bacaan,(3) membaca teks dan mencari jawaban atas pertanyaan, (4) mempertimbangkan jawaban, (5) meninjau ulang secara menyeluruh, (6) member contoh berdasarkan teks bacaan. Model SQ4R memiliki enalm langkah pembelajaran, mulai dari survey (penelitian pendahuluan), Question (Bertanya), read (membaca), recite (bercerita kembali menggunakan kata-kata sendiri), review (meninjau kembali), dan reflect (memberikan contoh dari bahan bacaan).. Model SQ4R ini memiliki beberapa kelebihan, diantaranya (1) membangkitkan rasa ingin tahu siswa, (2) memiliki kesempatan untuk mengajukan pertanyaan serta menemukan jawaban, dan (3) materi yang dibaca lebih dapat diresapi dan diingat dalam waktu yang lama. Dalam penerapan model pembelajaran tersebut, guru dapat memvariasikan pembelajaran dengan berbagai sarana dan media pembelajaran, salah satunya dengan menggunakan media teks cerita rakyat.

Media teks cerita rakyat dapat digunakan orang tua dan guru sebagai sarana mendidik dan membentuk kepribadian anak melalui transmisi budaya (Itadz,2008:19). Dengan menggunakan media teks cerita rakyat ini, diharapkan mampu melatih kemampuan membaca serta mampu melatih pemahaman siswa mengenai isi cerita yang telah dibaca siswa, karena bahasa yang digunakan pada cerita rakyat mudah dipahami siswa, dan isi dari teks cerita rakyat lebih menarik perhatian siswa. Melalui teks cerita rakyat pembelajaran dapat lebih menyenangkan dan siswa lebih antusias dalam pembelajaran (Safitri,2014).

Berdasarkan uraian sebelumnya, maka dilakukan penelitian yang berjudul "Pengaruh Model Pembelajaran Survey, Question, Read, Recite, Review, Reflect Berbantuan Media Teks Cerita Rakyat Terhadap Kompetensi Membaca Pemahaman Mata Pelajaran Bahasa Indonesia Kelas V Sekolah Dasar"

\section{Metode}

Penelitian ini dilaksanakan pada semester 2 Tahun Ajaran 2018 di kelas V SD Gugus Pattimura, Denpasar Selatan. Jenis penelitian yang dilakukan dalam penelitian ini adalah penelitian kuantitatif dengan desain eksperimental yaitu quasi eksperiment (Eksperimen Semu). Bentuk desain eksperimen semu yang digunakan adalah "Desain Penelitian Nonequivalent Control Group Design". 
Dalam desain ini terdapat dua kelompok sampel yang terdiri dari kelompok eksperimen dan kelompok kontrol sebagai subjek penelitian yang akan dibandingkan. Rancangan ini menggunakan pre test sebagai penyetaraan kelompok. Secara skematis, rancangan eksperimen nonequivalent control group design yang digunakan pada penelitian ini sebagai berikut.

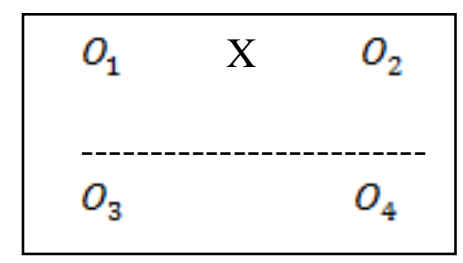

(Sumber: Sugiyono, 2017:79)

Gambar 1. Desain Eksperimen menggunakan Desain Penelitian Nonequivalent Control Group Design

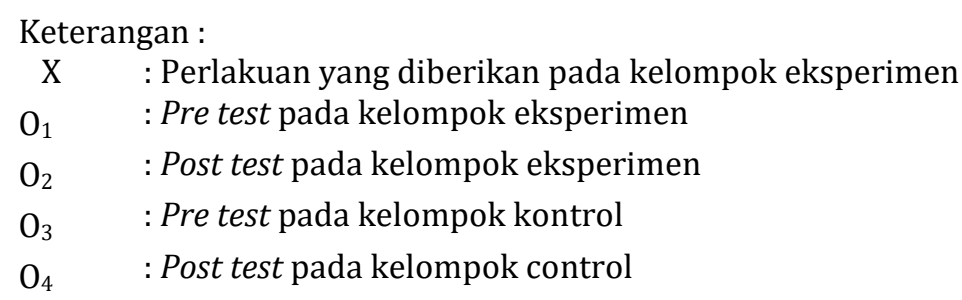

Teknik yang digunakan dalam penyetaraan kelompok adalah dengan menggunakan uji t. Setelah diberikan perlakuan yaitu dengan memberikan model pembelajaran $S Q 4 R$ berbantuan media teks cerita rakyat kepada kelompok eksperimen dan memberikan pembelajran konvensional kepada kelompok kontrol. Kemudian setelah diberikan perlakuan, dilakukan post test untuk mengetahui kompetensi membaca pemahaman.

Populasi penelitian ini adalah seluruh siswa kelas V SD Gugus Pattimura Denpasar Selatan Tahun Ajaran 2018, yang terdiri dari 8 kelas dalam 5 Sekolah Dasar yang berjumlah 341 siswa. Setelah mengetahui populasi, langkah selanjutnya adalah menentukan sampel penelitian. Teknik pengambilan sampel pada penelitian ini adalah random sampling. Pemilihan sampel penelitian ini dilakukan tanpa pengacakan individu melainkan pengacakan kelas karena kelas, sehingga setiap kelas mendapatkan peluang yang sama untuk menjadi sampel penelitian. Penentuan sampel yang dipilih dalam penelitian ini dilakukan dengan cara pengundian. Hasil pengundian tersebut diperoleh dua kelas yang dijadikan sampel penelitian, yaitu kelas VA SD Negeri 7 Sesetan dan kelas V SD Negeri 18 Sesetan. Setelah itu dua kelas hasil pengundian diberikan pre test, kemudian nilai atau skor dari hasil pre test yang dilakukan tersebut digunakan untuk penyetaraan kelas sampel. Untuk penyetaraan kelas sampel, nilai atau skor dari hasil pre-test seluruh populasi dianalisis menggunakan uji-t. Sebelum uji kesetaraan menggunakan uji-t, maka data hasil pre test diuji prasyarat yaitu normalitas dan homogenitas variansnya. Setelah diketahui kedua kelompok sampel setara, kemudian dilakukan pengundian yang kedua untuk menentukan kelas eksperimen dan kelas kontrol. Setelah dilakukan pengundian, kelas yang terpilih untuk menjadi kelas eksperimen adalah kelas VA di SD Negeri 7 Sesetan dan untuk kelas kontrol terpilih kelas V di SD Negeri 18 Sesetan.

Data yang dikumpulkan dalam penelitian ini adalah data kompetensi membaca pemahaman mata pelajaran bahasa Indonesia siswa kelas V SD Gugus Pattimura Denpasar Selatan Tahun Ajaran 2018. Metode pengumpulan data merupakan cara atau teknik yang dilakukan untuk mengumpulkan data penelitian. Metode pengumpulan data yang digunakan dalam penelitian ini adalah dengan metode tes. Pengumpulan data dengan metode tes. Pada penelitian ini data yang akan dianalisis adalah data mengenai kompetensi membaca pemahaman mata pelajaran bahasa Indonesia siswa sehingga untuk memperoleh data tersebut penelitian ini menggunakan instrumen bentuk tes. Tes yang akan digunakan untuk mengukur kompetensi pengetahuan berupa tes objektif dalam bentuk pilihan ganda biasa.

Tes objektif pilihan ganda biasa yang digunakan dalam penelitian ini terdiri dari 30 butir soal. Dalam tes ini dilakukan pengujian instrumen yaitu uji validitas, daya beda dan indeks kesukaran, dan reliabilitas.

Validitas yang digunakan dalam penelitian ini yaitu validitas isi dan validitas butir. Uji validitas isi dalam penelitian ini adalah menyusun instrumen berdasarkan kisi-kisi yang merujuk pada kurikulum. Dengan demikian, pengujian validitas isi instrumen penelitian ini juga dilakukan dengan melibatkan pendapat pakar/ahli. Untuk itu, dalam penyusunan tes penguasaan kompetensi membaca pemahaman 
mata pelajaran bahasa Indonesia dilakukan konsultasi dengan guru kelas. Untuk mengukur validitas butir tes kompetensi membaca pemahaman mata pelajaran bahasa Indonesia dalam bentuk objektif pilihan ganda digunakan rumus koefisien korelasi point biserial $\left(\mathrm{r}_{\mathrm{pbi}}\right)$ karena tes yang digunakan bersifat dikotomi. Nilai yang diperoleh kemudian dibandingkan dengan nilai yang diperoleh dari $r_{\text {tabel, }}$ dengan taraf signifikansi sebesar $5 \%$, jika $r_{\text {hitung }}>r_{\text {tabel, }}$, berarti instrumen dinyatakan valid dan jika $r_{\text {hitung }} \leq r_{\text {tabel, }}$, berarti instrumen dinyatakan tidak valid. Dari hasil perhitungan dengan rtabel pada taraf signifikansi 0,05 yaitu 0,344 terdapat 10 soal yang kurang dari $r_{\text {tabel }}(0,344)$ dan 20 butir soal yang lebih dari $r_{\text {tabel }}(0,344)$. Soal yang dinyatakan valid kemudian dilanjutkan diuji dengan uji daya beda.

Daya beda butir tes ialah kemampuan butir tes tersebut membedakan antara testee kelompok atas (pintar) dan testee kelompok bawah (lemah). Untuk menentukan kelompok atas dan kelompok bawah adalah dengan mengambil masing-masing 50\% dari jumlah sampel untuk kelompok atas dan kelompok bawah. Indeks daya beda yang digunakan untuk tes dalam penelitian ini adalah dari 0,4 sampai 1,00 dalam kategori cukup, baik dan baik sekali. Berdasarkan hasil pengujian, soal yang memiliki daya pembeda cukup yaitu sebanyak 12 butir soal, soal yang memiliki daya pembeda baik yaitu sebanyak 7 butir soal dan baik sekali sebanyak 1 butir soal dari 20 soal yang valid.

Soal yang telah diuji validitas butir tes dan uji daya beda kemudian diuji indeks kesukaran butir tes. Hasil uji tingkat kesukaran butir tes menunjukkan bahwa soal sukar sebanyak 4 butir, soal sedang sebanyak 11 butir, dan soal mudah sebanyak 5 soal dari 20 soal. Sedangkan indeks kesukaran perangkat tes yang digunakan yaitu 0,348 yang berada pada kriteria sedang.

Uji reliabilitas dilakukan hanya pada butir soal yang telah diuji validitas butir tes dan dinyatakan valid. Tes dalam penelitian ini bersifat dikotomi, sehingga rumus yang digunakan untuk uji reliabilitas tes adalah rumus Kuder Richardson (K-R. 20). Hasil perhitungan terhadap 20 butir tes yang dinyatakan valid dan memiliki daya beda cukup sampai dengan baik sekali, maka diperoleh $r_{11}=0,812$. Berdasarkan hal tersebut, maka $\mathbf{r}_{11}>0,70$ yang berarti tes objektif tipe pilihan ganda biasa pada penelitian ini tergolong reliabel.

Teknik yang digunakan untuk menganalisis data dalam penelitian ini adalah teknik analisis statisik deskriptif dan statistik inferensial. Stastistik. Teknik analisis statistik deskriptif dalam penelitian ini digunakan untuk mendeskripsikan penguasaan kompetensi membaca pemahaman mata pelajaran bahasa Indonesia siswa yang dibelajarkan menggunakan model pembelajarn SQ4R berbantuan media teks cerita rakyat dan penguasaan kompetensi membaca pemahaman mata pelajaran bahasa Indonesia siswa yang dibelajarkan dengan pembelajaran konvensional. Adapun data yang akan disajikan dalam statistik deskriptif adalah perhitungan mean, standar deviasi dan varians.

Instrumen yang telah diuji kualitasnya kemudian digunakan untuk mengukur kompetensi membaca pemahaman dalam mata pelajaran bahasa Indonesia siswa kelas V SD Gugus Pattimura Denpasar Selatan setelah diberikan perlakuan. Data hasil dari tes tersebut kemudian dianalisis menggunakan analisis statistik inferensial. Teknik analisis data yang dilakukan adalah uji hipotesis menggunakan uji t, sebelum dilakukan uji hipotesis, terlebih dahulu dilakukan uji prasyarat analisis yang meliputi uji normalitas sebaran data dan homogenitas varians.

Uji Normalitas dimaksudkan untuk mengetahui apakah sebaran data skor kompetensi membaca pemahaman dalam mata pelajaran bahasa Indonesia siswa masing-masing kelompok berdistribusi normal atau tidak sehingga dapat menentukan teknik analisis datanya. Uji Normalitas sebaran data dalam penelitian ini menggunakan Chi-kuadrat $\left(X^{2}\right)$. Hasil $X^{2}$ hitung kemudian dibandingkan dengan $X^{2}$ tabel, pada taraf signifikasi $5 \%$ dan derajat kebebasan $(\mathrm{dk})=(\mathrm{k}-1)$. Jika $X_{\text {hitung }} \leq X_{\text {tabel, }}$, maka tidak terdapat perbedaan antara $f_{o}$ dan $f_{e}$, sehingga $\mathrm{H}_{0}$ diterima yang berarti data berdistribusi normal. Jika $X^{2}$ hitung $>X_{\text {tabel, }}$ maka terdapat perbedaan antara $f_{o}$ dan $f_{e}$ dan $\mathrm{H}_{0}$ ditolak.

Uji Homogenitas dilakukan untuk menunjukkan bahwa perbedaan yang terjadi pada uji hipotesis benar-benar terjadi akibat adanya perbedaan varians antar kelompok, bukan sebagai akibat perbedaan dalam kelompok. Uji homogenitas dapat dilakukan apabila kelompok data tersebut berdistribusi normal. Uji homogenitas varians dilakukan dengan uji F. Pengujian dilakukan pada taraf signifikansi 5\% dengan derajat kebebasan untuk pembilang $\mathrm{n}_{1}-1$ dan derajat kebebasan untuk penyebut $\mathrm{n}_{2}-1$. Kriteria pengujian, jika $F_{\text {hit }} \leq F_{\text {tabel }}$ maka sampel homogen.

Data hasil penelitian yang telah diuji normalitas dan diuji homogenitas selanjutnya dilakukan uji hipotesis. Adapun hipotesis penelitian yang diuji yaitu $\mathrm{H}_{0}$ yang berbunyi tidak terdapat perbedaan yang signifikan kompetensi membaca pemahaman mata pelajaran bahasa Indonesia antara kelompok siswa yang dibelajarkan melalui model pembelajaran $S Q 4 R$ berbantuan media teks cerita rakyat dengan kelompok siswa yang dibelajarkan melalui pembelajaran konvensional pada siswa kelas V SD Gugus Pattimura Denpasar Selatan Tahun Ajaran 2018.

Analisis yang digunakan untuk menguji hipotesis penelitian ini adalah uji beda rerata (uji-t). Uji Hipotesis menggunakan uji-t dengan rumus polled varians. Dengan kriteria pengujian pada taraf 
signifikan $5 \%$ dengan $d k=n_{1}+n_{2}-2$, jika harga $t_{\text {hitung }} \leq t_{\text {tabel }}$, maka $H_{0}$ diterima, dan jika harga $t_{\text {hitung }}>t_{\text {tabel }}$ maka $\mathrm{H}_{0}$ ditolak. Berikut rumus uji-t yang digunakan

$$
t=\frac{\overline{\mathrm{x}}_{1}-\overline{\mathrm{x}}_{2}}{\sqrt{\frac{\left(\mathrm{n}_{1}-1\right) \mathrm{s}_{1}^{2}+\left(\begin{array}{c}
\mathrm{n}_{2}- \\
1
\end{array}\right) \mathrm{s}_{2}^{2}}{\mathrm{n}_{1}+\mathrm{n}_{2}-2}\left(\frac{1}{\mathrm{n}_{1}}+\frac{1}{\mathrm{n}_{2}}\right)}}
$$

(Sumber: Sugiyono, 2017: 197)

Keterangan:

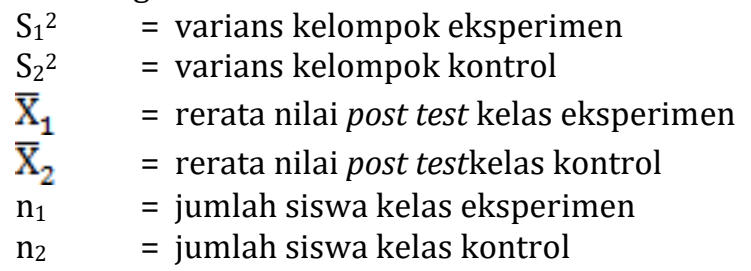

\section{Hasil dan Pembahasan}

Hasil analisis data dari kelompok eksperimen yang dibelajarkan dengan model pembelajaran Survey, Question, Read, Recite, Review, Reflect berbantuan media teks cerita rakyat dan kelompok kontrol yang dibelajarkan dengan pembelajaran konvensional disajikan pada Tabel 1.

Tabel 1. Deskripsi Kompetensi Membaca Pemahaman Mata Pelajaran Bahasa Indonesia

\begin{tabular}{lcc}
\hline Statistik Deskriptif & Kelompok Eksperimen & Kelompok Kontrol \\
\hline $\mathrm{N}$ & 39 & 37 \\
Nilai Tertinggi & 90 & 85 \\
Nilai Terendah & 50 & 40 \\
Mean & 73,18 & 65 \\
Standar Deviasi & 8,57 & 10,34 \\
Varians & 73,47 & 106,34 \\
\hline
\end{tabular}

Data yang diperoleh kemudian dianalisis menggunakan stastistik inferensial yang terdiri dari uji prasyarat dan uji hipotesis. Uji prasyarat meliputi uji normalitas sebaran data dan uji homogenitas varians.

Hasil uji normalitas kelompok eksperimen, diperoleh $\chi^{2}$ hitung $=6,600$, dengan taraf signifikan 5\% dan $\mathrm{dk}=\mathrm{k}-1=6-1=5$, maka diperoleh $\chi^{2}$ tabel $=11,070$. Berdasarkan perhitungan tersebut didapatkan $\chi^{2}$ hitung $<\chi^{2}$ tabel $(6,600<11,070)$ hal tersebut menunjukkan bahwa data hasil kompetensi pengetahuan IPA di kelompok eksperimen berdistribusi normal.

Hasil uji normalitas kelompok kontrol, diperoleh $\chi^{2}$ hitung $=6,850$, dengan taraf signifikan $5 \%$ dan dk $=\mathrm{k}-1=6-1=5$, maka diperoleh $\chi^{2}$ tabel $=11,070$. Berdasarkan perhitungan tersebut didapatkan $\chi^{2}$ hitung $<$ $\chi^{2}$ tabel $(6,850<11,070)$ hal tersebut menunjukkan bahwa data hasil kompetensi pengetahuan IPA di kelompok kontrol berdistribusi normal.

Uji homogenitas varian dilakukan dengan menggunakan uji-F. Hasil uji homogenitas, diperoleh $\mathrm{F}_{\text {hitung }}=1,45$, dengan taraf signifikan $5 \%$ dan $\mathrm{dk}(36,38)$, maka diperoleh $\mathrm{F}_{\text {tabel }}=1,71$. Hasil uji homogenitas pada kelompok eksperimen dan kelompok kontrol menunjukkan bahwa $F_{\text {hitung }}(1,45)<F_{\text {tabel }}$ $(1,71)$ yang berarti varians kedua kelompok tersebut homogen.

Data hasil penelitian yang telah diuji normalitas dan diuji homogenitas selanjutnya dilakukan uji hipotesis. Hipotesis penelitian yang diuji yaitu hipotesis nol $\left(\mathrm{H}_{0}\right)$. Hipotesis nol $\left(\mathrm{H}_{0}\right)$ yang diuji yaitu tidak terdapat pengaruh model pembelajaran $S Q 4 R$ berbantuan media teks cerita rakyat terhadap kompetensi membaca pemahaman mata pelajaran bahasa Indonesia siswa kelas V SD Gugus Pattimura Denpasar Selatan 2017/2018

Kriteria dari pengujian yaitu $\mathrm{H}_{0}$ ditolak jika $\mathrm{t}_{\text {hitung }}>\mathrm{t}_{\text {tabel, }}$, sedangkan $\mathrm{H}_{0}$ diterima jika $\mathrm{t}_{\text {hitung }} \leq \mathrm{t}_{\text {tabel, }}$, dimana $t_{\text {tabel }}$ didapatkan dari tabel distribusi t pada taraf signifikasi $5 \%$ dengan derajat kebebasan dk $=\left(n_{1}\right.$ $+\mathrm{n}_{2}-2$ ). Rekapitulasi hasil uji-t disajikan dalam Tabel 2. 
Tabel 2. Rekapitulasi Hasil Analisis Uji Hipotesis Kelompok Eksperimen dan Kelompok Kontrol

\begin{tabular}{lllllll}
\hline Kelompok & $\mathbf{N}$ & $\mathbf{d k}$ & $\overline{\boldsymbol{X}}$ & $\mathbf{S}^{\mathbf{2}}$ & $\mathbf{t}_{\text {hitung }}$ & $\mathbf{t}_{\text {tabel }}$ \\
\hline Eksperimen & 39 & \multirow{2}{*}{74} & 73,18 & 73,47 & \multirow{2}{*}{3,750} & 2,000 \\
Kontrol & 37 & & 65 & 106,34 & \\
\hline
\end{tabular}

Berdasarkan hasil analisis uji-t diperoleh $t_{\text {hitung }}=3,750$. Harga tersebut kemudian dibandingkan dengan harga $t_{\text {tabel }}$ dengan $\mathrm{dk}=39+37-2=74$ dan taraf signifikansi $5 \%$ sehingga diperoleh harga $t_{\text {tabel }}=$ 2,000 , karena $t_{\text {hitung }}>t_{\text {tabel }}$ maka $\mathrm{H}_{0}$ ditolak. Hal ini berarti terdapat perbedaan yang signifikan kompetensi membaca pemahaman mata pelajaran bahasa Indonesia antara kelompok siswa yang dibelajarkan melalui model pembelajaran $S Q 4 R$ berbantuan media teks cerita rakyat dengan kelompok siswa yang dibelajarkan melalui pembelajaran konvensional pada siswa kelas V SD Gugus Pattimura Denpasar Selatan Tahun Pelajaran 2017/2018. Sehingga dapat disimpulkan bahwa model SQ4R berpengaruh terhadap kompetensi membaca pemahaman mata pelajara bahasa Indonesia kelas V Sekolah Dasar.

Berdasarkan hasil post-test yang telah diberikan kepada kedua kelompok sampel penelitian, diperoleh hasil perhitungan analisis data yang menunjukkan bahwa nilai rata-rata dari kelompok siswa yang mengikuti pembelajaran melalui model pembelajaran $S Q 4 R$ berbantuan media teks cerita rakyat memperoleh nilai rata-rata sebesar $\bar{X}=73,18$, sedangkan kelompok siswa yang mengikuti pembelajaran konvensional memperoleh nilai rata-rata sebesar $\bar{X}=65$.

Dari perolehan nilai kompetensi membaca pemahaman mata pelajaran bahasa Indonesia pada kedua kelompok dapat diketahui bahwa kedua kelompok yang awalnya memiliki kemampuan setara, lalu setelah diberikan treatment yang berbeda, perolehan nilai kompetensi membaca pemahaman mata pelajaran bahasa Indonesia mengalami perbedaan.

Perbedaan yang signifikan kompetensi membaca pemahaman mata pelajaran bahasa Indonesia kelompok eksperimen dan kelompok kontrol terjadi karena perbedaan pemberian treatment yang diberikan saat pembelajaran. Kelompok eksperimen diberikan pembelajaran dengan menerapkan model pembelajaran $S Q 4 R$ berbantuan media teks cerita rakyat memiliki nilai rata-rata yang lebih tinggi dibandingkan dengan kelompok kontrol yang tidak menerapkan model pembelajaran $S Q 4 R$ berbantuan media teks cerita rakyat.

Penerapan model pemebelajaran $S Q 4 R$ berbantuan media teks cerita rakyat dapat meningkatkan faktor-faktor yang mempengaruhi kompetensi membaca pengetahuan mata pelajaran bahasa Indonesia. Dengan adanya tahap survey pada awal pembelajaran, sehingga dapat membangkitkan rasa ingin tahu siswa tentang materi yang akan dipelajari, sehingga dapat membangkitkan motivasi siswa dalam belajar. Siswa diberikan kesempatan mengajukan pertanyaan dan mencoba menemukan jawaban dari pertanyaan yang telah disusun sendiri dengan melakukan kegiatan membaca. Dengan demikian, dapat mendorong siswa untuk dapat berpikir kritis, aktif dalam belajar dan pembelajaran yang bermakna. sehingga ketika pembelajaran berlangsung pada kelas eksperimen mereka terlihat bersemangat dan senang mengikuti pembelajaran. Interaksi siswa meningkat karena pada model ini siswa diberikan kesempatan untuk mengajukan pendapat serta diberikan kesempatan untuk berkomunikasi dan berinteraksi dengan temannya dalam menemukan dan memahami suatu konsep. Selain itu, penggunaan media berupa teks cerita rakyat dapat merangsang daya analisis siswa melalui informasi yang tersirat. Cerita juga dapat menanamkan rasa peka untuk bisa membedakan mana hal yang baik dan mana yang buruk, dapat menanamkan kesadaran tentang kebenaran, keadilan, kejujuran, keberanian, kesetiaan, pengorbanan dan kehormatan.

Hasil penelitian ini mendukung penelitian yang telah ada sebelumnya yang dilakukan oleh: (a) Ayu Suardani (2013) yang menyimpulkan bahwa terdapat perbedaan yang signifikan pengaruh model pembelajaran $S Q 4 R$ terhadap keterampilan membaca mata pelajaran bahasa Indonesia kelas V SD Gugus I , (b) Dwiani Safitri (2014:Vol.2) menyimpulkan bahwa terdapat perbedaan secara signifikan pengaruh model pembelajaran Master berbantuan media teks cerita rakyat terhadap keterampilan membaca siswa pada pelajaran bahasa Indonesia kelas V SDN 12 Padangsambian.

Berdasarkan paparan tersebut, dapat dikatakan bahwa model pembelajaran $S Q 4 R$ berbantuan media teks cerita rakyat berpengaruh terhadap kompetensi membaca pemahaman mata pelajaran bahasa Indonesia siswa kelas V SD Gugus Pattimura Denpasar Selatan 2017/2018.

\section{Simpulan dan Saran}

Berdasarka hasil penelitian dan pembahasan dapat disimpulkan yaitu (1)kompetensi membaca pemahaman mata pelajaran bahasa Indonesia kelompok eksperimen diperoleh $X=73,18$ dan rerata 
persentase kompetensi membaca pemahaman mata pelajaran bahasa Indonesia kelompok eksperimen, M\% $=73,18 \%$. Rerata persentase kompetensi membaca pemahaman mata pelajaran bahasa Indonesia tersebut kemudian dikonversikan pada tabel PAP skala lima, sehingga dapat diketahui kompetensi membaca pemahaman mata pelajaran bahasa Indonesia berada pada katagori cukup, (2) kompetensi membaca pemahaman mata pelajaran bahasa Indonesia kelompok kontrol diperoleh $X=65$ dan rerata persentase kompetensi membaca pemahaman mata pelajaran bahasa Indonesia kelompok kontrol $65 \%$. Rerata persentase kompetensi membaca pemahaman mata pelajaran bahasa Indonesia tersebut kemudian dikonversikan pada tabel PAP skala lima, sehingga dapat diketahui kompetensi pengetahuan matematika siswa kelompok kontrol berada pada kategori cukup, (3) Terdapat pengaruh model pembelajaran $S Q 4 R$ berbantuan media teks cerita rakyat terhadap kompetensi membaca pemahaman mata pelajaran bahasa Indonesia siswa kelas V SD Gugus Pattimura Denpasar Selatan 2017/2018. Itu terbukti dari hasil analisis uji t diperoleh thitung $=3,75$. Harga tersebut kemudian dibandingkan dengan harga ttabel dengan $\mathrm{dk}=39$ $+37-2=74$ dan taraf signifikansi 5\% sehingga diperoleh harga ttabel =2,00, karena thitung $>$ ttabel maka Ho ditolak. Rata-rata kompetensi membaca pemahaman mata pelajaran bahasa Indonesia siswa kelompok eskperimen lebih dari rata-rata kompetensi membaca pemahaman mata pelajaran bahasa Indonesia siswa kelompok kontrol $(\overline{\boldsymbol{X}}=73,18>\overline{\boldsymbol{X}}=65)$. Sehingga dapat disimpulkan bahwa model pembelajaran Survey, Question, Read, Recite, Review, Reflect berbantuan media teks cerita rakyat berpengaruh terhadap kompetensi membaca pemahaman mata pelajaran bahasa Indonesia siswa kelas V SD Gugus Pattimura Denpasar Selatan Tahun Pelajaran 2017/2018.

Berdasarkan hasil penelitian ini, maka dapat disampaikan beberapa saran antara lain (1) kepada guru, Guru hendaknya dapat menambah wawasannya mengenai inovasi pembelajaran sehingga mampu menerapkan ataupun mengembangkan pembelajaran di kelas secara lebih inovatif dan bervariasi agar dapat memberikan dampak positif dalam meningkatkan kompetensi pengetahuan siswa. Salah satu model pembelajaran yang dapat diterapkanoleh guru adalah model pembelajaran $S Q 4 R$ berbantuan media teks cerita rakyat. (2) kepada kepala sekolah, Berdasarkan temuan penelitian, disarankan kepada kepala sekolah agar dapat menggunakan hasil penelitian ini sebagai pendukung sumber belajar guru dalam meningkatkan kualitas pembelajaran dengan menciptakan pembelajaran yang menggembirakan, serta menyediakan sarana yang maksimal untuk menunjang pembelajaran agar siswa semakin termotivasi untuk belajar dan memanfaatkan sarana tersebut untuk mengoptimalkan kompetensi siswa sehingga mutu sekolah menjadi semakin meningkat sehingga sekolah mampu menghasilkan siswa yang memiliki output berkualitas. (3) kepada peneliti lain, Peneliti lain agar menggunakan hasil penelitian ini sebagai pedoman untuk melakukan penelitian selanjutnya.

\section{Daftar Rujukan}

Agung, A.A. Gede. 2013. Buku Ajar Evaluasi Pendidikan. Singaraja: Universitas Pendidikan Ganesha.

Agung, A.A. Gede. 2014. Buku Ajar Metodologi Penelitian Pendidikan. Malang: Aditya Media Publishing.

Arikunto, Suharsimi. 2014. Prosedur Penelitian. Jakarta: PT. Rineka Cipta.

Arikunto, Suharsimi. 2016. Dasar-Dasar Evaluasi Pendidikan.Jakarta: Bumi Aksara.

Arikunto, Suharsimi. 2017. Dasar-Dasar Evaluasi Pendidikan.Jakarta: Bumi Aksara.

Dalman. 2017. Keterampilan Membaca. Jakarta: Rajawali Pers.

Dantes, 2012. Metode Penelitian. Yogyakarta: C.V Andi Offset.

Dantes, 2017. Desain Eksperimen dan Analisis Data. Depok: Rajawali Pers.

Daryanto dan Sudjendro, Herry. 2014. Wacana bagi Guru SD Siap Menyongsong Kurikulum 2013. Yogyakarta: Gava Media.

Dewi, Erni Ratna. 2018. Metode Pembelajaran Modern Dan Konvensional Pada Sekolah Menengah Atas. Jurnal Ilmu Pendidikan, Keguruan, dan Pembelajaran Vol. 2 No. 1 Hal. 44-52. Tersedia Pada: https://ojs.unm.ac.id/pembelajar/article/view/5442.

Faisal, Taufina, 2016. Mozaik Penilaian Pembelajaran Bahasa dan Apresiasi Sastra Indonesia di Sekolah Dasar. Bandung: CV. Angkasa. 
Itadz. 2008. Cerita Untuk Anak Usia Dini. Yogyakarta: Tiara Wacana.

Japa dan Suarjana. 2015. Buku Ajar Matematika. Singaraja: Universitas Pendidikan Ganesha.

Japa dan Suarjana. 2015. Buku Ajar Pendidikan Matematika III. Singaraja: Universitas Pendidikan Ganesha.

Kemendikbud. 2013. Permendikbud Nomor 81A Tahun 2013. Jakarta: Kementerian Pendidikan dan Kebudayaan

Kemendikbud. 2014. Permendikbud Nomor 57 Tahun 2014. Jakarta: Kementerian Pendidikan dan Kebudayaan

Kemendikbud. 2014. Permendikbud Nomor 103 Tahun 2014. Jakarta: Kementerian Pendidikan dan Kebudayaan.

Kosasih. 2014. Strategi Belajar dan Pembelajaran Implementasi Kurikulum 2013. Bandung: Yrama Widya. Kurniaman, Otang, Eddy Noviana. 2013. Penerapan Kurikulum 2013 dalam Meningkatkan Keterampilan, Sikap, dan Pengetahuan. Jurnal Primary Program Studi Pendidikan Guru Sekolah Dasar Fakultas Keguruan dan Ilmu Pendidikan Universitas Riau Vol. 6 No. 2 Hal. 389-396. Tersedia Pada: https://ejournal.unri.ac.id/index.php/JPFKIP/article/download/4520/4314.

Kurniasih, Imas dan Berlin Sani. 2014. Sukses Mengimplementasikan Kurikulum 2013. Jakarta: Kata Pena.

Mulyati, Yeti. 2008. Keterampilan Berbahasa Indonesia. Jakarta: Universitas Terbuka.

Ngalimun. 2013. Strategi dan Model Pembelajaran. Yogyakarta: Aswaja Pressindo.

Pratiwi, Yuni dkk.2007. Bahasa Indonesia. Jakarta: Universitas Terbuka.

Rahim, Farida. 2011. Pengajaran Membaca di Sekolah Dasar. Jakarta: Bumi Aksara.

Rasjid, Yusniar. 2015. Pengaruh Model Pembelajaran Survey Question Read Reflect Recite Review (SQ4R) dengan Metode Talking Stick terhadap Keterampilan Metakognisi dan Hasil Belajar Biologi Siswa SMAN 9 Makassar. JURNAL BIOTEK, Volume 3 Nomor 1 Hal. 170-183. Tersedia Pada: http://journal.uin-alauddin.ac.id/index.php/biotek/article/view/1104.

Rosdiana, Yusi dkk. 2007. Bahasa dan Sastra Indonesia di SD. Jakarta:Universitas Terbuka.

Rusman. 2017. Belajar dan Pembelajaran Berorientasi Standar Proses Pendidikan. Jakarta: Kencana.

Safitri, Dwiani Ni Md. 2014. Pengaruh Model Pembelajaran Master Berbantuan Media Cerita Rakyat Terhadap Keterampilan Membaca Siswa Pada Pembelajaran Bahasa Indonesia Kelas V SDN 12 Padang Sambian. Tersedia pada https://ejournal.undiksha.ac.id/index.php/JJPGSD/article/view/1960/1707 (diakses tanggal 9 Januari 2017).

Setyosari, Punaji. 2013. Metode Penelitian Pendidikan \& Pengembangan. Jakarta: Prenadamedia Group.

Shoimin, Aris. 2014. 68 Model Pembelajaran Inovatif dalam Kurikulum 2013. Yogyakarta: Ar-Ruzz Media

Solchan T. W, dkk. 2014. Pendidikan Bahasa Indonesia si SD. Jakarta: Universitas Terbuka.

Suardani, Ni L.A. 2013. Pengaruh Model Pembelajaran SQ4R Terhadap Keterampilan Membaca dalam Pembelajaran Bahasa Indonesia Siswa Kelas V SD Gugus I Denpasar Selatan, (online), Vol 2. Tersedia pada https://ejournal.undiksha.ac.id/index.php/JJPGSD/article/view/968/838 (diakses tanggal 7 Januari 2017).

Sudijono, Anas. 2015. Pengantar Evaluasi Pendidikan. Jakarta: PT. RajaGrafindo Persada.

Sugiyono. 2017. Metode Penelitian Pendidikan. Bandung: Alfabeta. 
Sugiyono. 2017. Metode Penelitian Kuantitatif, Kualitatif, dan R\&D. Bandung: Alfabeta Sugiyono. 2017. Statistika Untuk Penelitian. Bandung: Alfabeta Sukardi. 2011. Evaluasi Pendidikan Prinsip \& Operasionalnya. Jakarta: Bumi Aksara Susanto, Ahmad. 2013. Teori Belajar \& Pembelajaran di Sekolah Dasar. Jakarta: Kencana Tarigan, Henry Guntur. 2015. Membaca Sebagai Suatu Keterampilan Berbahasa. Bandung: Angkasa. Uno, Hamzah dan Satria Koni. 2012. Assessment Pembelajaran .Jakarta: Bumi Aksara. Wati, Ega Rima. 2016. Ragam M7edia Pembelajatan. Kata Pena.

Yusuf, Muri. 2015. Asesmen dan Evaluasi Pendidikan. Jakarta: Prenadamedia Group. 